\title{
Proprioceptive activities to postural balance of the elderly - systematic review
}

\author{
Atividades proprioceptivas para o equilíbrio \\ postural de idosos - revisão sistemática
}

\section{Actividades propioceptivas para el equilibrio postural de las personas mayores - revisión sistemática}

\section{Adriano Drummond, Clarissa Cardoso dos Santos Couto Paz, Ruth Losada de Menezes*}

Universidade de Brasília (UnB), Brasília, DF, Brazil

\begin{abstract}
Introduction: Proprioceptive activities are commonly described for control of the postural balance of the elderly in order to avoid falls. But, there is no consensus on which ones can significantly improve balance or on intervention and assessment protocols. Objective: To investigate which proprioceptive activities are specific to static and dynamic postural balance of the elderly through a systematic review. Method: This is a systematic review based on PRISMA recommendation, by surveying PubMed, Medline, LILACS, Scielo and EBSCO databases. The period considered for the search was from 2006 to 2016, using the following descriptors - aged, proprioception, exercise therapy, and postural balance for articles in English, Portuguese or Spanish. Randomized and non-randomized clinical trials were included using the PEDro scale to analyze the methodological quality of the studies. Results: Eight articles were included with different protocols, without standardization of evaluation and intervention, but, which demonstrated improvement of functional
\end{abstract}

\footnotetext{
*AD: Doctoral Student, e-mail: pos.adriano.unb@gmail.com CCSCP: PhD, e-mail: clarissacardoso@unb.br RLM: PhD, e-mail: ruthlosada@unb.br
} 
abilities. Different kinds of walk, muscular strengthening exercises, stretching, postural oscillations and Yoga patterns for the improvement of functional abilities. Conclusion: The association of static and dynamic activities can contribute to the improvement of functional abilities, but it cannot be affirmed that they are specific for postural control, given the lack of standardization of exercise protocols and evaluation tools.

Keywords: Aged. Exercise Therapy. Proprioception. Postural Balance.

\section{Resumo}

Introdução: Atividades proprioceptivas são comumente descritas para o controle do equilíbrio postural de idosos, no intuito de se evitar quedas. Mas não há um consenso acerca de quais podem melhorar significativamente o equilíbrio, bem como os protocolos de intervenção e avaliação. Objetivo: Investigar quais atividades proprioceptivas são específicas para o equilíbrio postural estático e dinâmico de idosos, por meio de uma revisão sistemática. Método: Trata-se de uma revisão sistemática baseada na recomendação PRISMA, por meio das bases de dados PubMed, Medline, LILACS, Scielo e EBSCO. O período considerado para a busca foi de 2006 a 2016, utilizando-se os descritores idosos, propriocepção, treinamento físico, e equilíbrio postural para artigos nos idiomas em inglês, português ou espanhol. Foram incluídos os ensaios clínicos randomizados e não-randomizados, com a utilização da escala PEDro para a análise da qualidade metodológica dos estudos. Resultados: Foram elencados 8 artigos que abordaram diferentes protocolos, sem padronização de avaliação e intervenção, mas demonstraram a melhora de algumas habilidades funcionais. Destacam-se as diferentes caminhadas, exercícios de fortalecimento muscular, alongamento, oscilações posturais e padrões de Yoga para a melhora de habilidades funcionais. Conclusão: A associação de atividades estáticas e dinâmicas podem contribuir para a melhora de habilidades funcionais, mas não se pode afirmar que sejam específicos para o controle postural, diante da falta de padronização dos protocolos de exercícios e de instrumentos de avaliação.

Palavras-chave: Idosos. Treinamento Físico. Propriocepção. Equilíbrio Postural.

\section{Resumen}

Introducción: Las actividades propioceptivas se conocen comúnmente para el control del equilibrio postural de los ancianos, con el fin de evitar caídas. Pero no hay consenso sobre cuáles pueden mejorar significativamente el equilibrio, así como los protocolos de intervención y evaluación. Objetivo: Investigar qué actividades propioceptivas son específicas para el equilibrio postural estático y dinámico de los ancianos, a través de una revisión sistemática. Método: Se trata de una revisión sistemática basada en la recomendación PRISMA, a través de las bases de datos PubMed, Medline, LILACS, Scielo y EBSCO. El período considerado para la búsqueda fue de 2006 a 2016, utilizando los descriptores ancianos, propiocepción, entrenamiento físico, y equilibrio postural para artículos en los idiomas en inglés, portugués o español. Se incluyeron los ensayos clínicos aleatorizados y no aleatorizados, con la utilización de la escala PEDro para el análisis de la calidad metodológica de los estudios. Resultados: Se destacan las diferentes caminatas, ejercicios de fortalecimiento muscular, estiramiento, oscilaciones posturales y patrones de Yoga para la mejora de habilidades funcionales. Conclusión: La asociación de actividades estáticas y dinámicas puede contribuir a la mejora de habilidades funcionales, pero no se puede afirmar que sean específicas para el control postural, ante la falta de estandarización de los protocolos de ejercicios y de instrumentos de evaluación.

Palabras clave: Anciano. Ejercicio. Propiocepción. Balance Postural. 


\section{Introduction}

Proprioception involves information generated by the mechanoreceptors, which are located in articulations, tendons, muscles, and skin, allowing some notion of the positioning of the human body regarding its orientation in the space or in relation to movement [1]. Postural balance is kept by the interaction of sensorial and neuromotor systems, enabling adaptation to a static or dynamic situation, regarding one's ability to keep the body positioning according to the stability limits [2].

However, the aging process might generate a deficit in the maintenance of this control when responding to unbalance external and internal stimuli. The review of sensorial systems in the elderly body balance by Ricci etal. [3] evidenced a reduction in the sharpness of the vestibular, visual and proprioceptive systems when compared to young adult people. Thus, unbalance reactions might become slower, generating a risk of falling [4-6]. The older the person is, the greater the instability of the frontal plane becomes [7], for example. And, as a response to this instability, the displacement of the weight discharge to the front part of the foot sole might occur when the elderly remains in the orthostatic position [8].

Postural control might also suffer influence from the hippocampus and thus changes in this region might promote lack of this functional ability [9]. Even cardiovascular conditions influence themaintenance of balance and require close attention to the elderly's blood pressure, which might present a sharp decrease risking their stability [10].

Neuromuscular training and the regular practice of physical activities are factors that contribute to the maintenance of the functionality, balance, and prevention of falls [11]. Promoting some stimuli through exercise programs for over three hours a week tends to present better results for the elderly [12]. More specifically, muscular strengthening and aerobic exercises are recommended as a strategy to prevent those events [13]. However, there is evidence that muscular strengthening benefits the dynamic stability, while proprioceptive stimuli favor the static balance [14]. Water exercises are also recommended, regarding activities of low and moderate intensity and taking into consideration their advantages in relation to the practice of these exercises [15]. Even activities taught to be done at home might present positive results in relation to this objective, regarding stretching, walks, sitting and standing up exercises along with postural control in the sitting position [16].
However, the need for a detailed analysis of the results presented in the literature regarding activities carried out as a response to the proprioceptive stimuli, the objective of maintaining postural balance and, consequently, preventing the risk of falls becomes evident, since treatments follow differentiated protocols due to the patients' different necessities, and the evaluation of this functional condition is developed with different instruments [2].

The objective of this research was, therefore, to investigate, through a systematic review, which proprioceptive activities are specific for the static and which for the dynamic postural balance of aged people.

\section{Methods}

This is a systematic review based on the PRISMA recommendation [17], addressing the theme of proprioceptive exercises and the postural balance of the elderly.

The search was carried out between August and September 2016, using the uniterms: idosos/aged, propriocepção/proprioception, treinamento físico/ exercise therapy, and equilíbrio postural/postural balance. The uniterms were listed in the descriptors (Descs) of the Health Virtual Library, using the words in Portuguese, and in the Mesh of the webpage PubMed, using the words in English. The data bases accessed were Scielo, Medline, PubMed, LILACS and EBSCO.

In the data bases Medline and PubMed, the uniterms were associated with the Boolean operator "AND" as follows: "aged" AND "proprioception" AND "exercise therapy" AND "postural balance". In Scielo, the association carried out was between the words: "idosos" (aged) AND "propriocepção" (proprioception); "idosos" (aged) AND "propriocepção" (proprioception) AND "treinamento físico" (exercise therapy); "idosos" (aged) AND "propriocepção" (proprioception) AND "equilíbrio postural" (postural balance). In LILACS, the association was between "aged" AND "proprioception" AND "exercise therapy"; and "aged" AND "proprioception" AND "postural balance". Finally, in the data base EBSCO, the uniterms associated were "aged" AND "proprioception", "aged" AND "postural balance", and "aged" AND "exercise therapy".

A differentiated association of descriptors in the different data bases was necessary due to the results obtained with the search. Equal attempts of association 
of uniterms in the data bases sometimes generated 'no result found'. Therefore, only those that presented at least one scientific paper were considered.

Eligibility criteria included: papers published up to 10 years ago, written in Portuguese, English or Spanish and characterized as randomized and non-randomized clinical assays, aiming at plausibility of interventions and results. Also, the use of exercises for the lower limbs regarding static and/or dynamic activities [4] was considered, using equipment or not and carried out on the floor. As a data comparison criterion, those that presented pre and post-therapy evaluations were considered, regardless of follow-up report, since the objective was to identify acute alterations. Finally, the authors evaluated postural balance, regardless of the evaluation of other functional aspects.

Potentially relevant studies were included after title and abstracts were verified. Next, the same reviewers carried out, individually, the reading of the whole texts and selected them according to the eligibility criteria. After that, relevant data were extracted: objectives of the study, sampling, exercise program data, frequency of activities and main results.

The papers excluded were: those with institutionalized elderly, or evaluating aged people with osteoarthritis, osteoporosis, neurological diseases, vestibular malfunction or ophthalmopathies that are unusual in the aging process or those that presented interventions in water therapy.

The PEDro scale was used as a tool to quantify the methodological quality of the studies. Despite being a more detailed tool for randomized clinical assays, meeting the criteria 1,10 and 11 can already legitimize the generalization and interpretation of non-randomized clinical assays [18].

As a final search strategy, the analysis of references of the eligible papers was considered to verify the possibility of including some study that had not been identified in the pre-determined data bases.

Two evaluators carried out the search individually and followed the same strategy to deal with the preselected data bases in all processes to extract and obtain data, without communicating to each other the results obtained, until the search was ended. Only papers selected by both evaluators were initially included. When a paper was selected by one of the evaluators only, a third reviewer analysed that same article to decide whether it would be included or not.

\section{Results}

The flowchart below shows that the number of documents included in the discussion after the eligibility criteria was 10 papers.

Figure $\mathbf{l}$ - Flowchart of the systematic review different phases.

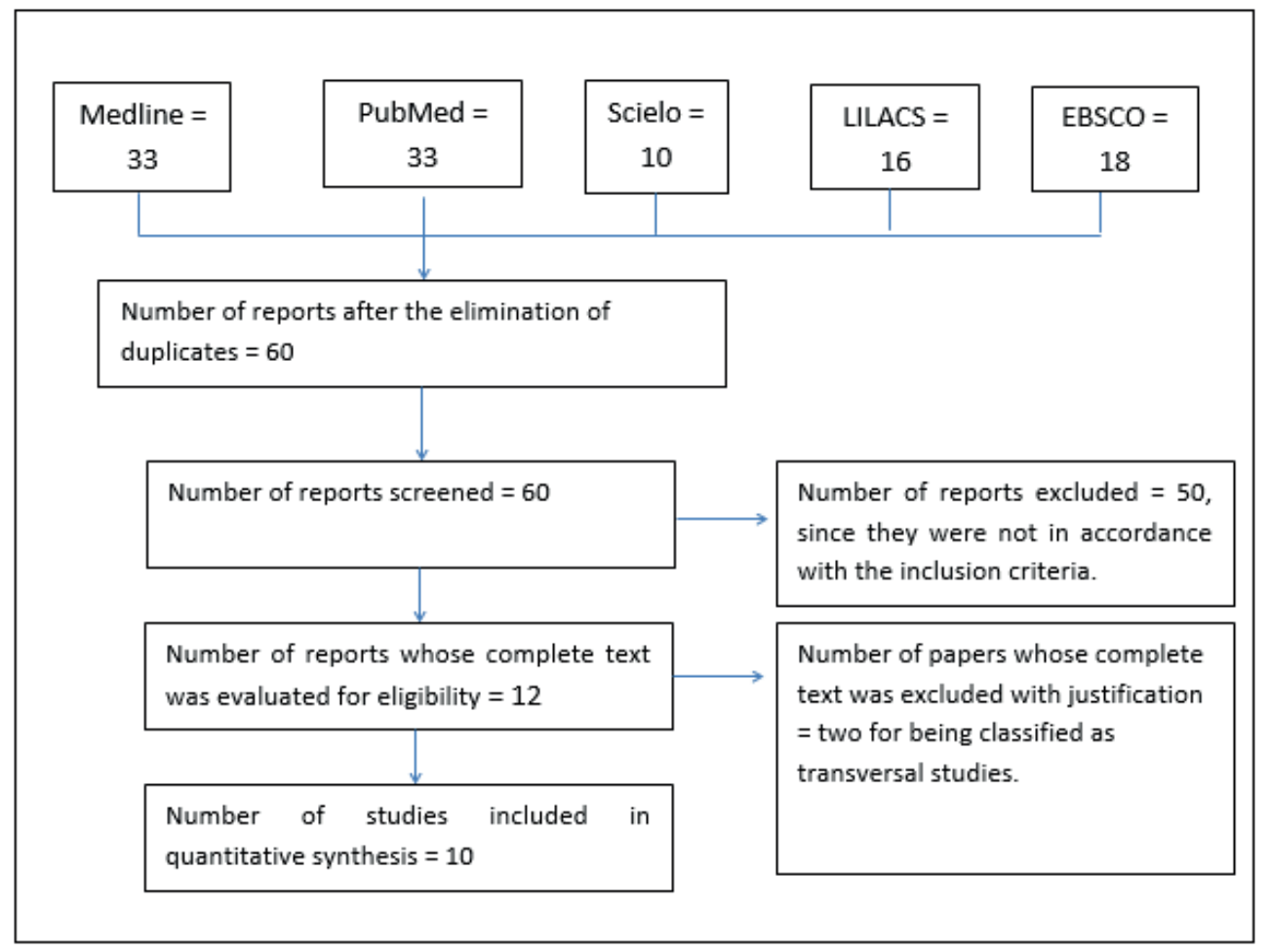


The intervention methods described favored the improvement of the postural balance through the combination of static and dynamic activities, and one of the reports presented the proposal of verifying the results of Yoga exercises [5, 19 - 27].

One paper presented the strategy of 24 weeks of therapy [25], three recommended 12 weeks of therapy [19, $20,26]$, two suggested 8 weeks [5,23], one paper recommended 6 weeks [21], two other papers recommended 5 weeks $[22,25]$ and another one suggested 4 weeks [24]. The frequency of participation in activities was established between twice and three times a week, varying between 20-65 minutes per session.

Figure 2 - Characteristics of the papers included in the review (Brasília, 2016).

(to be continued)

\begin{tabular}{|c|c|c|c|c|c|}
\hline $\begin{array}{c}\text { Authors/ } \\
\text { year }\end{array}$ & Objectives & Sample & Program of exercises & $\begin{array}{l}\text { Frequency of } \\
\text { activities }\end{array}$ & Results \\
\hline $\begin{array}{l}\text { Sohn et al.; } \\
2015 \text { [5] }\end{array}$ & $\begin{array}{l}\text { To evaluate the } \\
\text { effect of the } \\
\text { exercises on } \\
\text { proprioception, } \\
\text { postural balance } \\
\text { and probability } \\
\text { of fall. }\end{array}$ & $\begin{array}{l}18 \\
\text { elderly. }\end{array}$ & $\begin{array}{l}\text { CG: activities of daily life. EG: exercises } \\
\text { to strengthen the quadriceps, hamstring, } \\
\text { gastrocnemius, maximus, medium and } \\
\text { minimum gluteus. Initially with } 3 \text { series of } \\
10 \text { repetitions with a } 50 \% \text { da maximum load } \\
\text { (ML), after } 5 \text { weeks, } 3 \text { series of } 10 \text { repetitions } \\
\text { with a } 70 \% \mathrm{ML} \text {; at the end, } 3 \text { series of } 7 \\
\text { repetitions with an } 85 \% \mathrm{ML} \text {. PG: exercises of } \\
\text { postural stability at different levels of difficulty. }\end{array}$ & 3 times a week. & $\begin{array}{l}\text { After } 8 \text { weeks, the } \\
\text { two therapy groups } \\
\text { presented an } \\
\text { increase in strength } \\
\text { and reduction in } \\
\text { the probability of } \\
\text { falls, with increase } \\
\text { in muscular power } \\
\text { capacity. }\end{array}$ \\
\hline $\begin{array}{l}\text { Todde et al.; } \\
2016 \text { [19] }\end{array}$ & $\begin{array}{l}\text { To evaluate } \\
\text { the effect of } \\
\text { supervised } \\
\text { vigorous } \\
\text { exercises on the } \\
\text { functional ability. }\end{array}$ & $\begin{array}{l}20 \\
\text { elderly. }\end{array}$ & $\begin{array}{l}\text { Warming phase ( } 10 \text { minutes) considering } \\
60 \% \text { of the resting heart rate }- \text { slow } \\
\text { movements, including stretching the main } \\
\text { muscle groups of the lower and upper } \\
\text { limbs and trunk. Active phase ( } 45 \text { minutes) } \\
\text { considering between } 60 \text { and } 84 \% \text { of the } \\
\text { resting heart rate - forward and backward } \\
\text { short walks, going up and down steps, upper } \\
\text { and lower limb exercises with resistance to } \\
\text { elastic bands, which were changed, regarding } \\
\text { their resistance each } 4 \text { weeks. Recovery } \\
\text { phase (10 minutes) considering less than } \\
60 \% \text { of the resting heart rate - postural } \\
\text { control and exercises of spine mobility in } \\
\text { quadruped position, and stretching. }\end{array}$ & $\begin{array}{l}3 \text { times a week, } \\
\text { for } 65 \text { minutes. }\end{array}$ & $\begin{array}{l}\text { After } 12 \\
\text { weeks, there } \\
\text { was increase } \\
\text { in muscular } \\
\text { strength, balance, } \\
\text { flexibility and } \\
\text { agility. }\end{array}$ \\
\hline $\begin{array}{l}\text { Kelley et al.; } \\
2014 \text { [20] }\end{array}$ & $\begin{array}{l}\text { To evaluate } \\
\text { the effects of } \\
12 \text { weeks of } \\
\text { therapeutic Yoga } \\
\text { on walking speed, } \\
\text { postural balance } \\
\text { and mobility. }\end{array}$ & $\begin{array}{l}13 \\
\text { elderly. }\end{array}$ & $\begin{array}{l}\text { Breathing exercises ( } 5 \text { minutes), body } \\
\text { awareness ( } 5 \text { minutes), postural exercises } \\
\text { standing, sitting and lying ( } 40 \text { minutes), } \\
\text { and meditation (10 minutes). }\end{array}$ & $\begin{array}{l}\text { Twice a week, } \\
\text { for } 60 \text { minutes. } \\
\text { It was necessary } \\
\text { to take part in at } \\
\text { least } 19 \text { sessions } \\
\text { altogether. }\end{array}$ & $\begin{array}{l}\text { After } 12 \text { weeks, } \\
\text { there was } \\
\text { improvement of } \\
\text { the walk speed, } \\
\text { postural balance } \\
\text { and mobility. }\end{array}$ \\
\hline
\end{tabular}


( 0 be continued)

\begin{tabular}{|c|c|c|c|c|c|}
\hline $\begin{array}{c}\text { Authors/ } \\
\text { year }\end{array}$ & Objectives & Sample & Program of exercises & $\begin{array}{c}\text { Frequency of } \\
\text { activities }\end{array}$ & Results \\
\hline $\begin{array}{l}\text { Kristinsdottir } \\
\text { et al.; } 2014 \\
{[21]}\end{array}$ & $\begin{array}{l}\text { To evaluate } \\
\text { the effects of } \\
\text { combined stimuli } \\
\text { of mechanical, } \\
\text { proprioceptive } \\
\text { and vestibular } \\
\text { exercises, and } \\
\text { prevention of } \\
\text { fall in postural } \\
\text { control, functional } \\
\text { ability, self- } \\
\text { confidence in } \\
\text { activities of daily } \\
\text { life, and frequency } \\
\text { of fall in unstable } \\
\text { elderly. }\end{array}$ & $\begin{array}{l}37 \\
\text { elderly. }\end{array}$ & $\begin{array}{l}\text { Warming up for } 15 \text { minutes, with a } \\
\text { comfortable speed walk and stretching } \\
\text { of the muscle groups of the lower limbs. } \\
\text { Proprioceptive therapy, mainly for the lower } \\
\text { limbs, vestibular and visual control training, } \\
\text { facilitation and integration of vestibular and } \\
\text { proprioceptive stimuli, and movements } \\
\text { preventing falls. }\end{array}$ & $\begin{array}{l}\text { Three times } \\
\text { a week, for } \\
45 \text { minutes, } \\
\text { approximately. }\end{array}$ & $\begin{array}{l}\text { After } 6 \text { weeks, } \\
\text { there was } \\
\text { performance } \\
\text { improvement } \\
\text { in all aspects } \\
\text { evaluated. }\end{array}$ \\
\hline $\begin{array}{l}\text { Treml et al.; } \\
2013 \text { [22] }\end{array}$ & $\begin{array}{l}\text { To evaluate the } \\
\text { effects of a } \\
\text { proprioceptive } \\
\text { therapy program } \\
\text { on balance, } \\
\text { mobility, flexibility } \\
\text { and falls. }\end{array}$ & $\begin{array}{l}32 \\
\text { elderly. }\end{array}$ & $\begin{array}{l}\text { GC: Use of rocker board, round freeman } \\
\text { board, square freeman board, individual } \\
\text { trampoline (unipedal and bipodal } \\
\text { support), use of skate to move the hips } \\
\text { (orthostatism), and twist disc. GE: circuit } \\
\text { with obstacles (blindfolded), and use of a } \\
\text { videogame platform. }\end{array}$ & $\begin{array}{l}\text { Twice a week; } \\
30 \text { minutes of } \\
\text { stimulus. }\end{array}$ & $\begin{array}{l}\text { After } 5 \text { weeks, } \\
\text { the proprioceptive } \\
\text { therapy with } \\
\text { virtual reality was } \\
\text { shown to be more } \\
\text { efficient than the } \\
\text { traditional one. }\end{array}$ \\
\hline $\begin{array}{l}\text { Alfieri et al.; } \\
2012 \text { [23] }\end{array}$ & $\begin{array}{l}\text { To investigate } \\
\text { the effects of } \\
\text { exercises focused } \\
\text { on postural } \\
\text { control. }\end{array}$ & $\begin{array}{l}23 \\
\text { elderly. }\end{array}$ & $\begin{array}{l}\text { Warming up ( } 5 \text { min) with forward, lateral } \\
\text { and backward walks. Stretching ( } 20 \text { min) } \\
\text { of the hip, knee, ankle and trunk muscles. } \\
\text { Coordination ( } 25 \text { min) throwing the ball } \\
\text { one to another, or hitting balls with a } \\
\text { bat, sometimes with one foot in front of } \\
\text { the other. Relaxation ( } 5 \text { min): breathing } \\
\text { exercises, sitting. }\end{array}$ & $\begin{array}{l}\text { Twice a week; } 1 \\
\text { hour of activities. }\end{array}$ & $\begin{array}{l}\text { After } 8 \text { weeks, } \\
\text { there was } \\
\text { improvement } \\
\text { regarding the } \\
\text { support base, } \\
\text { displacement in } \\
\text { anteroposterior } \\
\text { direction with } \\
\text { open eyes and } \\
\text { blindfolded; and } \\
\text { reduction in the } \\
\text { displacement in } \\
\text { the anteroposterior } \\
\text { direction in } \\
\text { individuals with } \\
\text { open eyes. }\end{array}$ \\
\hline $\begin{array}{l}\text { do } \\
\text { Nascimento } \\
\text { et al.; } 2012 \\
\text { [24] }\end{array}$ & $\begin{array}{l}\text { To analyze } \\
\text { the effect of } \\
\text { four weeks of } \\
\text { proprioceptive } \\
\text { therapy on } \\
\text { the elderly's } \\
\text { postural balance } \\
\text { measures }\end{array}$ & 9 elderly. & $\begin{array}{l}\text { Walking training on a track with } 4 \text { different } \\
\text { types of soil, progressively, with } 2 \mathrm{~m} \\
\text { distance between them, on which the } \\
\text { patients would go and come back, and the } \\
\text { return was timed. }\end{array}$ & $\begin{array}{l}\text { Twice a week, for } \\
20 \text { minutes. }\end{array}$ & $\begin{array}{l}\text { After } 4 \text { weeks, } \\
\text { there was } \\
\text { increase in } \\
\text { balance and } \\
\text { reduction in the } \\
\text { time of execution } \\
\text { of the walking } \\
\text { training. }\end{array}$ \\
\hline $\begin{array}{l}\text { Fernandes } \\
\text { et al.; } 2012 \\
{[25)}\end{array}$ & $\begin{array}{l}\text { To verify the } \\
\text { effects of a } \\
\text { physical exercise } \\
\text { program on } \\
\text { walking and } \\
\text { functional } \\
\text { mobility of the } \\
\text { elderly. }\end{array}$ & 8 elderly. & $\begin{array}{l}\text { Warming-up (5-minute walk), global } \\
\text { stretching ( } 15 \text { minutes), multi-sensorial } \\
\text { exercises ( } 30 \text { minutes) - walking, strength, } \\
\text { balance and proprioception, in pre- } \\
\text { determined circuits. }\end{array}$ & Twice a week. & $\begin{array}{l}\text { After } 24 \text { weeks, } \\
\text { there was } \\
\text { increase in the } \\
\text { length of steps } \\
\text { and walking } \\
\text { speed, improving } \\
\text { the functional } \\
\text { development. }\end{array}$ \\
\hline
\end{tabular}




\begin{tabular}{|c|c|c|c|c|c|}
\hline $\begin{array}{c}\text { Authors/ } \\
\text { year }\end{array}$ & Objectives & Sample & Program of exercises & $\begin{array}{l}\text { Frequency of } \\
\text { activities }\end{array}$ & Results \\
\hline $\begin{array}{l}\text { Dougherty } \\
\text { et al.; } 2011 \\
\text { [26] }\end{array}$ & $\begin{array}{l}\text { To evaluate the } \\
\text { effects of the use } \\
\text { of Nintendo Wii } \\
\text { balance platform } \\
\text { on balance and } \\
\text { proprioception. }\end{array}$ & 9 elderly. & $\begin{array}{l}\text { Training on a balance platform using an } \\
\text { interactive game. }\end{array}$ & $\begin{array}{l}\text { Three times a } \\
\text { week, for } 10 \\
\text { minutes }\end{array}$ & $\begin{array}{l}\text { After } 5 \text { weeks, } \\
\text { there was } \\
\text { improvement in } \\
\text { muscular strength } \\
\text { and balance. }\end{array}$ \\
\hline $\begin{array}{l}\text { Alfieri; } 2008 \\
\text { [27] }\end{array}$ & $\begin{array}{l}\text { To verify the } \\
\text { effects of a } \\
\text { proprioceptive } \\
\text { intervention } \\
\text { regular program } \\
\text { on the distribution } \\
\text { of the sole } \\
\text { pressure. }\end{array}$ & $\begin{array}{l}29 \\
\text { elderly. }\end{array}$ & $\begin{array}{l}\text { Warm up and flexibility ( } 10 \mathrm{~min}) \text {, with } \\
\text { walking, playing ball with the feet and } \\
\text { hands, stretching of the hip, knee, ankle } \\
\text { and paravertebral muscles. Strengthening } \\
\text { of lower muscle groups ( } 15 \text { min) with } \\
\text { resistance elastic bands - } 2 \text { series of } \\
20 \text { or } 15 \text { repetitions; proprioception } \\
\text { therapy ( } 30 \text { min), walking in different } \\
\text { directions, on different types of soil, } \\
\text { going over obstacles, use of rocker board } \\
\text { and trampoline, with bipodal or unipedal } \\
\text { support, with open eyes or blindfolded. }\end{array}$ & $\begin{array}{l}\text { Three times a } \\
\text { week, for } 1 \text { hour. } \\
\text { Walking, using } \\
\text { postural instability } \\
\text { equipment, } \\
\text { muscular } \\
\text { strengthening. }\end{array}$ & $\begin{array}{l}\text { After } 12 \text { weeks, } \\
\text { there was no } \\
\text { significant } \\
\text { alteration of the } \\
\text { distribution of the } \\
\text { sole pressure. }\end{array}$ \\
\hline
\end{tabular}

Regarding methodological quality, Table 1 indicates the information obtained using the PEDro scale, as expected the non-randomized studies presented lower score, considering the criteria evaluated by the scale.

Table 1- Bias control using the PEDro scale (Brasília, 2016)

\begin{tabular}{lcccccccccccc}
\hline Study & 1 & 2 & 3 & 4 & 5 & 6 & 7 & 8 & 9 & 10 & 11 & Score \\
\hline Sohn et al. [5] & 1 & 1 & 1 & 1 & 1 & 0 & 0 & 1 & 1 & 1 & 1 & 9 \\
Todde et al. [19] & 1 & 1 & 0 & 1 & 0 & 0 & 0 & 1 & 1 & 1 & 1 & 7 \\
Kelley et al. [20] & 1 & 0 & 0 & 0 & 0 & 1 & 1 & 0 & 0 & 1 & 1 & 5 \\
Kristinsdottir et al. [21] & 1 & 0 & 0 & 0 & 0 & 0 & 1 & 0 & 1 & 1 & 1 & 5 \\
Treml et al. [22] & 1 & 1 & 0 & 1 & 1 & 0 & 0 & 1 & 1 & 1 & 1 & 8 \\
Alfieri et al. [23] & 1 & 0 & 0 & 0 & 0 & 0 & 0 & 1 & 1 & 0 & 1 & 4 \\
Nascimento et al. [24] & 1 & 0 & 0 & 0 & 0 & 0 & 0 & 1 & 1 & 0 & 1 & 4 \\
Fernandes et al. [25] & 1 & 0 & 0 & 0 & 0 & 0 & 0 & 1 & 1 & 0 & 1 & 4 \\
Dougherty et al. [26] & 1 & 0 & 0 & 0 & 0 & 0 & 0 & 1 & 1 & 0 & 1 & 4 \\
Alfieri [27] & 1 & 0 & 0 & 0 & 0 & 0 & 0 & 1 & 1 & 0 & 1 & 4 \\
\hline Note: * Score - 1 (presents the criterion); 0 (does not present the criterion). ** Items of evaluation - 1: eligibility criteria; 2: randomized \\
allocation; 3: secret allocation; 4: similarity between groups; 5: blindfolded participation; 6: blindfolded therapists; 7: blindfolded evaluators; 8: \\
dimension of results; 9: analysis trough treatment intention; 10: intergroup statistical comparison; 11: accuracy and variability measurements.
\end{tabular}

\section{Discussion}

The exercises proposed by the authors resulted, in general, in improvement in the participants' postural control. Since the proprioceptive response must be diversified in relation to the several kinds of internal and external stimuli, it is necessary to consider the particularities of the participants so that the best option can be selected. 
The data were categorized as evaluation tools, types of activities and periods of intervention, for the discussion.

Evaluation tools

The authors used several types of evaluation, depending on the objective of the study, among these were: muscular strength test [5, 19,27], flexibility [19], time of walking speed $[5,20,21,23,24]$, mobility $[20$, 21], and postural balance [5, 19 - 27].

Todde et al. [19] inferred the degree of strength of lower limb muscles indirectly using the 30 -second test to stand up from the sitting position in a chair, in which during the determined time, the researcher measured how many times the elderly could perform the movement of sitting in a chair and standing up. This function, according to the authors, requires strength from the muscles of the lower limbs to execute functional activities such as getting out of a car, standing up from the sitting position, walking and going upstairs. However, to be sure of the increase in muscular strength, it is necessary to carry out a quantitative analysis of the data, through a load cell, for example, since at the end of the therapy, the participants might have acquired ability and motor coordination for this test, improving their performance in the test, which might mask the real dimension of the inference. Sohn et al. employed the Biodex System 3 to quantify muscle effort through the isokinetic peak prior and after training protocols, contributing to a greater accuracy of results.

Also, regarding muscular strength, Dougherty et al. [26] concluded that there was an increase in the strength of trunk and lower limb groups. However, the evaluations applied were the Berg Balance Scale and a videogame platform for the postural balance analysis. There is some incoherence in concluding that there was increase in muscular strength, since no specific tool was used to verify that, even if there was improvement in the test results. Again, this might only mean that the elderly acquired ability and motor coordination for the test.

Flexibility could be evaluated in the report by Todde et al. [19], for both lower limbs, through the Chair Sitand-Reach Test, and the upper limbs using the Back Scratch Test. In the former, the volunteer sitting in a chair stretches both lower limbs and tries to reach the feet with both hands. The distance between their fingers and the foot while keeping the spine erect is measured and if there is reduction in distance (in $\mathrm{cm}$ ), some improvement in flexibility can be concluded. In the latter, the volunteer has to put their hand on the shoulder of the same side and slip it towards the lower portion of the back; the opposite hand, with the palm turned backwards and positioned on the lumbar region tries to reach the other hand. The distance between the two hands is also evaluated, evidencing whether there was increase in flexibility or not.

The walking speed test was used by Sohn et al. [5], Kelley et al. [20], Kristinsdottir et al. [21], Alfieri et al. [23], and Nascimento et al. [24]. Due to the neurophysiological complexity of the walking function, the measurement of the speed of execution of this function might be a valuable analysis for the risk of falls [28] and, therefore, for the evaluation of dynamic body balance. Those authors used this tool coherently to report the results obtained in their studies.

Postural balance was analyzed using the Berg Balance Scale (BBS) (EEB) [22, 24, 26], for Performance Oriented Mobility Assessment (POMA) [22], of BESTest [20], which is an evaluation that includes components of other scales and tests, such as EEB, Timed Up and Go (TUG) and the Ataxia Test Battery, which also analyzes biomechanical restrictions and stability during walking. Functional balance and mobility were tested using Foot Up and Go (FUG) [21], like TUG, only differing in distance, since FUG considers 2.4 meters to walk, turn and go back to the starting point, watching the time of execution of the distance covered. TUG was used by Fernandes et al. [25] and Alfieri et al. [23] with the same purpose. For the static postural balance, the Guralnik test was also a resource used by Alfieri and collaborators [23]. It consists of a battery of tests that include static balance evaluation, ability to stand up from the sitting position in a chair and walking speed. The modified Romberg test was chosen by Nascimento et al. [24] and refers to the analysis of static balance with open and closed eyes. The resource employed by Alfieri [27] in 2008 was a computerized baropodometry system with a pressure platform coupled to a software, asking the participants' bipedal support on the platform, with open eyes and later on with closed eyes. The functional reach and unipodal support test were used by Treml [22].

There is no standardization of the postural balance evaluation in the studies analyzed. More suitable conclusions might have been described by the authors after using tools sensitive to this objective. It is also necessary to limit the intervention methods that can differentiate results regarding static and dynamic stimuli. The combination of static and dynamic exercises was observed in the same protocol, using a single type of evaluation in some cases, which only informed the static or the dynamic ability. Also, the presence of clinical 
reasoning is necessary for the planning of interventions with the participants.

\section{Types of activities}

Stimulating lower limbs with exercises was a point in common between most of the authors. In a static or dynamic way, using muscular strengthening exercises, walking in different directions, training static stability control, going up and down the stairs and stretching were all described in the protocols adopted. Kelley et al [20], when developing a sequence of Yoga specific exercises with participants, which included stimuli in orthostatism, either sitting or lying, reported that not only did the postural control improved, but also the walking speed and mobility were favored. Therefore, slower activities contributed to the authors' goals, conversely to what had been defended by Garcia et al. [29] regarding the need to prioritize muscular strengthening and power of the lower limbs [29] to alter the walking speed. Other alternative techniques were already used aiming at observing their influence on the postural balance of older people, such as Tai Chi Chuan, which also promotes slow and controlled movements. Despite not evaluating their participants in relation to their walking speed, Konig et al. noticed some improvement in balance, using the TUG, EEB and Romberg tests [30].

Walking training is a therapeutic option adopted to improve the dynamic balance. With this proposal, Nascimento et al. [24] designed an exclusive route of walking training with four different types of soil, in sequence, with a total length of 8 metres, so that the elderly could walk, going ahead and coming back on the adapted track. This protocol allowed them to observe some improvement in balance through the Berg Balance Scale and the walking speed. Practicing walking and the speed test culminated in a scientific aspect that characterized the specific training. This has already been explained by Miyasike-da-Silva [31] and justifies the performance improvement. However, the Berg Balance Scale also evaluates the static balance, even if it was not trained in this study, and demonstrated the participants' evolution. It seems relevant to highlight that both types of balance require complex interaction between the sensorial systems and this is favored in the dynamic training [32].

Todde et al. [19] asked their participants to walk backwards and forwards in a short distance, to go up and down the stairs, to do muscular strengthening exercises with the lower limbs associated to the upper limbs, during most of the sessions. Also, varying this protocol, Alfieri [27] designed a training in which, walking in different directions was stimulated as well as loss of balance on a trampoline, rocker board and muscle strengthening exercises for the lower limbs along with throwing a ball with both feet and hands. The walking training has been associated to other stimuli to increase body balance, due to the complexity of the interaction between systems with the purpose of promoting a more satisfactory result for the elderly [33, 34]. However, results reported by Todde et al. presented increase in muscular strength, agility, flexibility and balance, differing from the results put forward by Alfieri, since there was no significant alteration regarding pre and post-training data.

About the protocol for the muscular strengthening exercises, again referring to the study developed by Alfieri [27], the approach was selective to the sole flexor muscles, knee extensor and flexor muscles, flexors, adductors, hip abductors and extensor muscles, using elastics and following the prescription of 2 series of 20 repetitions and, if the load was increased, 2 series of 15 repetitions. But, it is necessary to determine individually the maximum volunteer load force and the training individual calculation, according to Sohn et al. [5], who calculated the percentage of maximum voluntary contraction of each participant for a proper training program. However, both studies used the strengthening protocol three times a week, and the results might be more expressive regarding functional abilities [35]. Since the training of muscular strength of lower limb groups enables improvement of postural balance [36]. The resting time between the series was not informed. This might be a relevant factor for a sedentary public, as the participants investigated.

Later, Alfieri et al. [23] obtained different results from those published in 2008, after adopting different evaluation measures and training protocol. Using static and dynamic post urography, those authors described improvement in the support base and anteroposterior movement with open or closed eyes. During the sessions, the training procedures adopted were strictly dynamic, in which the elderly had to walk in different directions, throw the ball one to another with their hands and hit the ball with a bat, alternating the support base. Not only was the proposed activity altered but also the author's method of evaluation, possibly due to the limitation of the study published in 2008.

A different protocol was used by Kristinsdottir and Baldursdottir [21], in which the participants started the 
training with a 15-minute walk, at a comfortable speed, and they could use the protection bars as a support to their hands. Later, they stretched the muscles of the lower groups to start a program of multisensory stimuli including: proprioceptive training, in which the participants were stimulated to control their body weight distribution during the body movements and were discouraged to use their hands as eventual support, if they felt necessary. Vestibular training, in which the ocular movement was guided without moving the head and moving the head with closed eyes. Finally, the movements to prevent falls, about which the participants were instructed to react to sudden disturbance, going a step forward to prevent the fall and when their stability was challenged by a manual push to different directions. This protocol also reflected the beginning of a specific training, since it sought to stimulate the different sensory systems related to the ability to keep the postural balance, but it differed from the others due to the vestibular component.

Dougherty et al. [26] used a videogame platform aiming at promoting dynamic postural control with nine participants, who were old people from the community, for 10 minutes per session, three times a week for five weeks and concluded that there was increase in muscular strength of the trunk and lower limb groups, in addition to the improvement in postural balance. The study by Craig et al. [37] can explain partially this benefit, those authors demonstrated that the elderly tend to present increase in co-contraction of the anterior tibialis and the medial gastrocnemius muscles to keep their balance. Therefore, taking into consideration the stimulus of these muscles during the videogame platform activity, the muscular co-contraction might help the articular stabilization for the relevant activity and, complementarily, the type of challenge proposed might make the proprioceptive sharpness in relation to the ankle articulation either easier or more difficult. Similar results from the research by Treml et al. [22], in which the participants in the experimental group, who used a videogame platform, obtained better postural balance result from the stimulus with four different games and a walking training while blindfolded, when compared to the control group that carried out balance exercises on boards. These results might be related to the effort carried out by the elderly to succeed in their interaction with the games. Also, the proprioceptive mechanism might overcome the visual and the vestibular ones, as a compensation, when referring to the adaptation to the stimuli [39].
Periods of intervention

The authors of the papers surveyed planned from four to twenty-four weeks of intervention and, in all of them, it was possible to notice improvement in the postural balance of the old people selected in their studies. It seems relevant to emphasize that, despite the great variation between the protocols, the analysis of the results obtained was only of the acute effect, therefore, four weeks with a specific walking training [24], or twelve weeks with a varied protocol [19, 20, 27], or even 24 weeks of multisensory stimuli [25], might generate beneficial effects for those specific purposes, but the time the results lasted was not measured. Another finding was that the protocols used did not vary the stimulus during the weeks the activities were developed. Therefore, four weeks of the same stimulus might generate positive results regarding functional abilities.

However, this should not exempt further studies from adopting a follow up system to confirm the maintenance of the results obtained and their magnitude. In a study with old women, Rebelatto et al. [40] could observe that the bilateral manual grasping strength was kept after 18 weeks of rest. The group of participants was submitted to 58 weeks of strengthening and flexibility exercises. However, the 18 weeks of rest was planned in the middle of the program, after 29 weeks of stimuli. Even if analyzing the proprioceptive response was not the objective, it seems relevant to observe that both strength and flexibility influence on the postural control and, therefore, the maintenance of their properties is vital to prevent falls, for example [2].

Similar results described in this study were confirmed in other review studies, which reported moderate efficiency of the several stimuli proposed by other authors, immediately after intervention, regarding balance training, motor coordination, muscular strength and other types, to obtain improvement of the postural balance. However, this does not lead to a concrete conclusion to define the specific activity that would guide the construction of a specific protocol, even for old people with specific diseases such as diabetes $[41,42]$.

This study presents limitations that can be controlled in further reviews of the theme. One of them is in relation to the number of data bases and, consequently, the unfeasibility of analyzing all papers published in the period defined and, therefore, more detailed data related to the object of study. Also, strategically, the papers chosen were those characterized as nonrandomized clinical assays. However, the selective 
process of these publications revealed that evidence can be found in studies with this design. This fact might be a motivation for the development of other systematic reviews. The choice of other idioms for the selection of papers is an important factor to complement the findings of this research.

\section{Conclusion}

The results led to the conclusion that static and dynamic activities such as walking in different directions and speeds, muscular strength exercises for the lower limbs, postural balance when facing alterations of the support base, stretching the large muscle groups as well as patterns from yoga activities improved some functional abilities, but such activities cannot be established as specific for postural balance, since there is no standardization of the protocol or evaluation tools.

It is necessary to control the number of weeks of training and to produce more evidence regarding a suitable follow-up of the results obtained.

\section{References}

1. Riemann BL, Lephart SM. The sensorimotor system, part II - the role of propriocpetion in motor control and functioinal joint stability. J Athl Train. 2002;37(1):80-4.

2. Horak FB. Postural orientation and equilibrium: what do we need to know about neural control of balance to prevent falls? Age Ageing. 2006;35 Suppl 2:ii7-ii11.

3. Ricci NA, Gazzola JM, Coimbra IB. Sistemas sensoriais no equilíbrio corporal de idosos. Arq Bras Cien Saúde. 2009;34(2):94-100.

4. Kanekar N, Aruin AS. The effect of aging on anticipatory postural control. Exp Brain Res. 2014;232(4):1127-36.

5. Sohn J, Kim S. Falls study: Proprioception, postural stability, and slips. Biomed Mater Eng. 2015;26 Suppl 1:S693-703.

6. Lockhart TE., Smith JL., Woldstad. Effects of aging on the biomechanics os slips and falls. Hum Factors. 2005; 47(4):708-29.

7. Puszczalowska-Lizis E, Bujas P, Omorczyk J. Postural stability in women in the eighth and ninth decades of life. Acta Bioeng Biomech. 2016;18(3):115-21.
8. Machado AS, Bombach GD, Duysens J, Carpes FP. Differences in foot sensitivity and plantar pressure between young adults and elderly. Arch Gerontol Geriatr. 2016;63(1):67-71.

9. Beauchet O, Barden J, Liu-Ambrose T, Chester VL, Szturm T, Allali G. The relationship between hippocampal volume and static postural sway: results from the GAIT study. Age (Dordr). 2016;38(19):1-8.

10. Pasma JH, Bijlsma AY, Klip JM, Stijntjes M, Blauw GJ, Muller M, et al. Blood pressure associates with standing balance in elderly outpatients. Plos One. 2014;9(9):1-9.

11. Silva TO, Freitas RS, Monteiro MR, Borges SM. Avaliação da capacidade física e quedas em idosos ativos e sedentários da comunidade. Rev Bras Clin Med. 2010;8(5):392-8.

12. Sherrington C, Michaleff ZA, Fairhall N, Paul SS, Tiedemann A, Whitney J, et al. Exercise to prevent falls in older adults: an updated systematic review and meta-analysis. Br J Sports Med 2017;51:1749-57. doi:10.1136/bjsports-2016-096547.

13. Mat S, Tan MP, Kamaruzzaman SB, Ng CT. Physical therapies for improving balance and reducing falls risk in osteoarthritis of the knee: a systematic review. Age Ageing. 2015;44(1):16-24.

14. Lelard T, Ahmaidi S. Effects of physical training on agerelated balance and postural control. Neurophysiol Clin. 2015; 45(4-5): 357-69.

15. Resende SM, Rassi CM, Viana FP. Efeitos da hidroterapia na recuperação do equilíbrio e prevenção de quedas em idosas. Rev Bras Fisiot. 2008;12(1):57-63.

16. Tanaka EH, Santos PF, Silva MF, Botelho PFFB, Silva $\mathrm{P}$, Rodrigues NC, et al. The effect of supervised and home based exercises on balance in elderly subjects: a randomized controlled trial to prevent falls. Rev. Bras. Geriatr. Gerontol. 2016;19(3):383-97.

17. Moher D, Liberati A, Tetzlaff J, Altman DJ. Principais itens para relatar Revisões sistemáticas e Metaanálises: A recomendação PRISMA. Epidemiol Serv Saude. 2015;24(2):335-42.

18. Moseley AM, Sherrington C, Elkins MR, Herbert RD, Maher CG. Indexing of randomised controlled trials of physiotherapy interventions: a comparison of AMED, CENTRAL, CINAHL, EMBASE, hooked on Evidence, PEDro, PsycINFO and PubMed. Physiotherapy. 2009;95(3):151-6. 
19. Todde F, Melis F, Mura R, Pau M, Fois F, Magnani S, et al. A 12-Week Vigorous Exercise Protocol in a Healthy Group of Persons over 65: Study of Physical Function by means of the Senior Fitness Test. Biomed Res Int. 2016;1:1-6.

20. Kelley KK, Aaron D, Hynds K, Machado E, Wolff M. The effects of a therapeutic yoga program on postural control, mobility, and gait speed in community-dwelling older adults. J Altern Complement Med. 2014;20(12):949-54.

21. Kristinsdottir EK, Baldursdottir B. Effect of multisensory balance training for unsteady elderly people: pilot study of the "Reykjavik model". Disabil Rehabil. 2014;36(14):1211-8.

22. Treml CJ, Kalil Filho FA, Ciccarino RFL, Wegner RS, Saita CYS, Corrêa AG. O uso da plataforma Balance Board como recurso fisioterápico em idosos. Rev. Bras. Geriatr. Gerontol. 2013; 16(4):759-68.

23. Alfieri FM, Riberto M, Abril-Carreres A, Boldo-Alcaine M, Rusca-CastelletE, Garreta-Figuera R, et al. Effectiveness of an exercise program on postural control in frail older adults. Clin Interv Aging. 2012;7:593-8.

24. Nascimento LCGd, Patrizzi LJ, Oliveira CCES. Efeito de quatro semanas de treinamento proprioceptivo no equilíbrio postural de idosos. Fisioter Mov. 2012; 25(2):325-31.

25. Fernandes AMBL, Ferreira JJA, Stolt LROG, Brito GEG, Clementino ACCR, Sousa NM. Efeitos da prática de exercício físico sobre o desempenho da marcha e da mobilidade funcional em idosos. Fisioter. Mov. 2012;25:(4):821-30.

26. Dougherty J, Kancel A, Ramar C, Meacham C, Derrington $\mathrm{S}$. The effects of multi-axis balance board intervention program in an elderly population. Mo Med. 2011;108(2):128-32.
27. Alfieri MA. Distribuição da pressão plantar em idosos após intervenção proprioceptiva. Rev. Bras. Cineantropom. Desempenho Hum. 2008;10(2):137-42.

28. Fritz S, Lusardi M. White paper: walking speed: the sixth vital sign. J Geriatr Phys Ther. 2009;32(1):2-5.

29. Garcia PA, Dias JMD, Dias RC, Santos P, Zampa CC. Estudo da relação entre função muscular, mobilidade funcional e nível de atividade física em idosos comunitários. Rev Bras Fisioterapia. 2011;15(1):15-22.

30. Konig PR, Galarza E, Goulart NBA, Lanferdini FJ, Tiggeman CL, Dias CP. Effects of Tai Chi Chuan on the elderly balance: a semi-experimental study. Rev. Bras. Geriatr. Gerontol. 2014; 17(2):373-81.

31. Miyasike-da-Silva V, Gonçalves CT, Silva JJ, Gobbi LTB. Mobilidade de idosos em ambiente doméstico: efeitos de um programa de treinamento específico. Rev Bras Ativ Fis Saúde. 2003;8:5-19.

32. Lima CB, Secco CR, Miyasike VS, Gobbi LTB. Equilíbrio dinâmico: influencia das restrições ambientais. Rev Bras Cineantropom Desempenho Hum. 2001;3(1):83-94.

33. Fernandes AMBL, Ferreira JJA, Stolt LROG, Brito GEG, Clementino ACCR, Sousa NM. Efeitos da prática de exercício físico sobre o desempenho da marcha e da mobilidade funcional em idosos. Fisioter. Mov. 2012;25(4):821-30.

34. Rubira APFA, Silva MG, Carvalho TG, Sene M, Harakawa LSK, Rubira LA, Consolim-Colombo FM, et al. Efeito de exercícios psicomotores no equilíbrio de idosos. ConsSaude. 2014;13(1):54-61.

35. Lustosa LP, Silva JP, Coelho FM, Pereira DS, Parentoni AN, Pereira LSM. Efeito de um programa de resistência muscular na capacidade funcional e na força muscular dos extensores de joelho em idosas pré-frágeis da comunidade: ensaio clínico aleatorizado do tipo cross over. Rev Bras Fisioterapia. 2011;15(4):318-24. 
36. Faria JC, Machala CC, Dias RC, Dias JMD. Importância do treinamento de força na reabilitação da função muscular, equilíbrio e mobilidade de idosos. Acta Fisiatr. 2003;10(3):133-37.

37. Craig CE, Goble DJ, Doumas M. Proprioceptive acuity predicts muscle co-contraction of the tibialis anterior and gastrocnemius medialis in older adults' dynamic postural control. Neuroscience. 2016; 322:251-61.

38. Deshpande N, Simonsick E, Metter EJ, Ko S, Ferrucci L, Studenski S. Ankle proprioceptive acuity is associated with objective as well as self-report measures of balance, mobility, and physical function. Age (Dordr). 2016;38(53):1-9.

39. Wiesmeier IK, Dalin D, Maurer C. Elderly use proprioception rather than visual and vestibular cues for postural motor control. Front Aging Neurosci. 2015;7:1-14.
40. Rebelatto JR, Calvo JI, Orejuela LR, Portillo JC. Influência de um programa de atividade física de longa duração sobre a força muscular manual e a flexibilidade corporal de mulheres idosas. Rev Bras Fisiot. 2006;10(1):127-32.

41. Ites KI, Anderson EJ, Cahill ML, Kearney JA, Post EC, Gilchrist LS. Balance interventions for diabetic peripheral neuropathy: a systematic review. J Geriatr Phys Ther. 2011;34(3):109-16.

42. Kendrick D, Kumar A, Carpenter H, Zijlstra GAR, Skelton DA, Cook JR, et al. Exercise for reducing fear of falling in older people living in the community. Cochrane Cochrane Database Syst Rev. 2014;11:1-134.

Received in 22/07/2017

Recebido em 07/22/2017

Recibido en 22/07/2017

Approved in 28/08/2018

Aprovado em 08/28/2018

Aprobado en 28/08/2018 